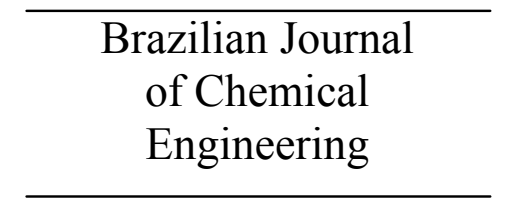

ISSN 0104-6632

Printed in Brazil

www.abeq.org.br/bjche

Vol. 28, No. 03, pp. 425 - 432, July - September, 2011

\title{
MODELLING OF ACID MINE DRAINAGE (AMD) IN COLUMNS
}

\author{
C. M. Bernardes de Souza and M. B. Mansur ${ }^{*}$ \\ Department of Metallurgical and Materials Engineering, Universidade Federal de Minas Gerais, \\ Phone: + (55) (31) 3409-1811, Fax: + (55) (31) 3409-1815, Av. Antônio Carlos 6627, \\ Campus da Pampulha, CEP: 31270-901, Belo Horizonte - MG, Brazil. \\ E-mail: marcelo.mansur@demet.ufmg.br
}

(Submitted: January 31, 2011 ; Revised: April 16, 2011 ; Accepted: June 21, 2011)

\begin{abstract}
A model is proposed in this paper to describe the generation of acid mine drainage (AMD) in leaching columns. The model considers: (i) Water flow through the column, which is calculated using the 1-D analytic solution of the Richards' equation assuming the existence of a similarity relationship between the water retention function and the water content profiles at a given time; and (ii) Pyrite oxidation weighted by microbiological effects occurring in spherical particles according to the shrinking core model. Mass balances of oxygen and pyrite were derived in order to evaluate the intrinsic oxidation rate and the pyrite fraction reacted with time and column position. The model was used to simulate a six month operation of a leaching column, which comprised successive weekly cycles of dry and wet periods. Simulation results demonstrated that AMD generation is strongly affected by the presence of microorganisms. A relative deviation of 5\% between simulation and experimental data was obtained.
\end{abstract}

Keywords: Acid mine drainage; Prediction; Columns; Environmental.

\section{INTRODUCTION}

Acid mine drainage (AMD) is one of the most important environmental problems facing the mining industry. Drainage waters are generated by chemical and microbiological reactions that occur simultaneously when sulphide minerals like pyrite $\left(\mathrm{FeS}_{2}\right)$ are exposed to oxygen and water. Such exposure produces acid that may dissolve relatively insoluble chemical species into free ionic species, or even secondary minerals like sulphates, carbonates and hydroxides. Consequently, water can dissolve and transport these more soluble chemical species (for example, $\mathrm{Cu}, \mathrm{Zn}, \mathrm{U}, \mathrm{As}, \mathrm{Pb}$, and many other metals) in quantities that may exceed water quality standards. Therefore, successful, cost-effective, proactive design and operation of mitigation measures for sulphidic geologic materials depend on an accurate prediction of future drainage chemistry and contaminant loadings.
A number of models to predict AMD have been proposed in the literature (Ericksson and Destouni, 1997; Bain et al., 2000; Schneider et al., 2002; Mayer et al., 2002; Nicholson et al., 2003). Water quality modelling using empirical, geochemical and complex models can assist with the interpretation of test work and monitoring results, and may improve the prediction of drainage chemistry and loadings (Martin et al., 2005). In fact, the prediction of AMD at mine sites is quite difficult due to its technical complexity and inherent uncertainties such as weather, soil characteristics, mineralogy, heap disposition, etc. Factors that complicate water quality prediction vary in scale from small to large, so the use of a phased approach to data collection and interpretation is still necessary.

A review made by Norecol Dames \& Moore Ltd. concluded that empirical models may not be statistically valid for mine sites with less than a few hundred data points (Mend Report, 2009). On the

*To whom correspondence should be addressed 
other hand, complex models normally require more intensive site specific studies and data with sufficient accuracy, which is not always available. In this context, the aim of this paper is to present a conceptually simple approach to simulate AMD in columns in order to gain insight into how drainage is affected by parameters such as microbiological effects, diffusion of oxygen, average particle radius and pyrite content.

\section{THEORY}

Two main aspects were considered in this approach: (1) Water infiltration patterns inside a cylindrical column, and (2) Chemical processes related to pyrite oxidation, including oxygen diffusion through spherical particles weighted by microbiological interaction. The first part of the model is the hydraulic description of water flow through the column, which was given by solving the Richards' equation without gravity, so the solution might be valid for short columns only. The second part of the model is the kinetic-diffusive description of pyrite oxidation, incorporating oxygen diffusion according to the shrinking core model (Levenspiel, 1972) including the microbiological effect on the generation of AMD. No significant neutralizing or competing metal reactions were assumed to occur. The model was used to simulate the intrinsic oxidation rate (IOR) and the pyrite reacted fraction with time.

\section{Hydraulic Description}

The hydraulic description of water flow through the column is given by the Richards' equation, which can be written as:

$\nabla \mathrm{q}+\frac{\partial \theta}{\partial \mathrm{t}}=0$

The existence of a similarity relationship between the water retention function $\theta(\mathrm{h})$ and the water content profiles $\theta(z)$, taken at fixed times as proposed by Prevedello et al. (2009), was assumed in this study. Due to this assumption, the hydraulic model is valid only for porous media with narrow size distribution (such soils show an abrupt humidity increase during water percolation). Under this hypothesis, the water content profile can be visualized as the water retention curve mirror image, so:

$$
\mathrm{z} \frac{\partial \theta}{\partial \mathrm{z}}=\mathrm{h}_{\mathrm{z}=\mathrm{z}} \frac{\partial \theta}{\partial \mathrm{h}_{\mathrm{z}=\mathrm{z}}}
$$

and the equation of Richards can be simplified to:

$$
\frac{\partial \theta}{\partial \mathrm{t}}=\frac{\partial}{\partial \mathrm{z}}\left[\mathrm{K}(\theta)\left(\frac{\mathrm{h}_{\mathrm{z}=\mathrm{z}}}{\mathrm{z}}-1\right)\right]
$$

subject to the following initial and boundary conditions:

Initial condition

$\mathrm{z} \geq 0 \quad \mathrm{t}=0 \quad \theta=\theta_{\mathrm{i}}$

Boundary condition

$$
\begin{array}{lll}
\mathrm{z}=0 & \mathrm{t}>0 & \theta=\theta_{0} \\
\mathrm{z} \rightarrow \infty & \mathrm{t} \geq 0 & \theta=\theta_{\mathrm{i}}
\end{array}
$$

Changing variables in Eq. (3) and remembering that $z=f(\theta, t)$ and $\frac{\partial \theta}{\partial t}=-\frac{\partial z}{\partial t} \frac{\partial z^{-1}}{\partial \theta}$, the equation of Richards can be written as:

$\frac{\partial \mathrm{z}}{\partial \mathrm{t}}=\left(1-\frac{\mathrm{h}_{\mathrm{z}=\mathrm{z}}}{\mathrm{z}}\right) \frac{\partial \mathrm{K}(\theta)}{\partial \theta}$

Integrating Eq. (5) from $\mathrm{t}=0$ to $\mathrm{t}=\mathrm{t}$ and between $\theta=\theta_{\mathrm{i}}$ and $\theta=\theta_{0}$ :

$\left(\frac{\mathrm{K}_{0}-\mathrm{K}_{\mathrm{i}}}{\theta_{0}-\theta_{\mathrm{i}}}\right) \mathrm{t}=\mathrm{z}+\mathrm{h}_{\mathrm{z}=\mathrm{z}} \ln \left(1-\frac{\mathrm{z}}{\mathrm{h}_{\mathrm{z}=\mathrm{z}}}\right)$

Therefore, Eq. (6), proposed by Prevedello et al. (2009), was used to describe the transient downward water infiltration inside the column. It must be highlighted that Eq. (6) is valid solely for the unsaturated zone; an analytical solution for the Richards' equation without gravity including the saturated zone was given recently by Barry et al. (2010). The dependence of $h$ with $\theta$ was obtained using the empirical relationship given by van Genutchen (1980):

$\frac{\theta-\theta_{\mathrm{r}}}{\theta_{0}-\theta_{\mathrm{r}}}=\left[1+(\alpha(\mathrm{h}))^{\mathrm{n}}\right]^{-\mathrm{m}}$

\section{Kinetic-Diffusive Description}

AMD generation due to pyrite oxidation depends on simultaneous events occurring in the three phase system during mineral oxidation (Elberling et al., 1994; Edwards et al., 2000).

With regard to the gaseous phase, it was assumed that oxygen transport within the column is governed by diffusive flow through the porous media, given by: 
$\theta_{\text {eq }} \frac{\partial \mathrm{C}_{\mathrm{o} 2}}{\partial \mathrm{t}}=\mathrm{D}_{\mathrm{e}} \frac{\partial^{2} \mathrm{C}_{\mathrm{o} 2}}{\partial \mathrm{z}^{2}}-\mathrm{S}_{0}$

where $\mathrm{S}_{0}$ represents the consumption of oxygen due to the oxidation reaction, given by:

$\mathrm{S}_{\mathrm{o}}=\mathrm{D}_{2} \frac{3(1-\theta)}{\mathrm{R}^{2}}\left(\frac{\mathrm{r}_{\mathrm{c}}}{\mathrm{R}-\mathrm{r}_{\mathrm{c}}}\right) \frac{\mathrm{C}_{\mathrm{o} 2}}{\mathrm{H}} \mathrm{f}_{\mathrm{m}}$

and the average shrinking radius $r_{c}$ is evaluated according to the shrinking core model (Levenspiel, 1972):

$\frac{\partial \mathrm{r}_{\mathrm{c}}}{\partial \mathrm{t}}=-\frac{\mathrm{D}_{\mathrm{w}}(1-\theta)}{\varepsilon \rho_{\mathrm{s}}} \frac{\mathrm{R}}{\mathrm{r}_{\mathrm{c}}\left(\mathrm{R}-\mathrm{r}_{\mathrm{c}}\right)} \frac{\mathrm{C}_{\mathrm{o} 2}}{\mathrm{H}} \mathrm{f}_{\mathrm{m}}$

Both effects are weighted by the microbiological factor $f_{m}$, which accounts for the effect of microorganisms on the AMD generation. In this study, $f_{m}$ is an adjustable parameter that was obtained by data fitting. In Eq. (8), the air volumetric equivalent content $\theta_{\text {eq }}$ is given by:

$\theta_{\text {eq }}=\theta_{\mathrm{a}}+\frac{\theta_{\mathrm{w}}}{\mathrm{H}}$

The model was solved according to the following initial and boundary conditions:

Initial condition

$$
\mathrm{z} \geq 0 \quad \mathrm{t}=0 \quad \mathrm{r}_{\mathrm{c}}=0.95 \mathrm{R} \quad \mathrm{C}_{\mathrm{o} 2}=\mathrm{C}_{\mathrm{o} 2 \mathrm{i}}
$$

Boundary condition

$$
\begin{array}{ccc}
\mathrm{z}=0 & \mathrm{t}>0 & \mathrm{C}_{\mathrm{o} 2}=\mathrm{C}_{\mathrm{o} 2 \mathrm{i}} \\
\mathrm{z} \rightarrow \infty & \mathrm{t} \geq 0 & \frac{\partial \mathrm{C}_{\mathrm{o} 2}}{\partial \mathrm{z}}=0
\end{array}
$$

The numerical solution was obtained by using the method of finite differences. The column was divided into $\mathrm{n}$ discrete stages and the equations were solved using the LU method.

Regarding the solid phase, a pyrite mass balance for each stage $\mathrm{i}$ was done to quantify the oxidized pyrite mass along the column during time interval $\Delta \mathrm{t}$ as:

$\mathrm{m}_{\mathrm{i}}=\frac{\mathrm{PS}}{\varepsilon} \frac{\mathrm{S}_{0, \mathrm{i}}(1-\theta) \pi \mathrm{D}^{2} \mathrm{H} \Delta \mathrm{t}}{4 \mathrm{~N}}$

and the total mass oxidized in the column at each time is given by:
$\mathrm{m}_{\mathrm{o}}=\sum_{\mathrm{i}=1}^{\mathrm{N}} \mathrm{m}_{\mathrm{i}}$

Finally, the liquid phase was modelled by assuming that pyrite oxidation occurs according to the following global reaction:

$$
\mathrm{FeS}_{2}+1 / 2 \mathrm{H}_{2} \mathrm{O}+15 / 4 \mathrm{O}_{2} \rightarrow \mathrm{Fe}^{+3}+2 \mathrm{SO}_{4}^{-2}+\mathrm{H}^{+}
$$

so transient $\mathrm{pH}$ and sulphate concentration in the aqueous phase were calculated by, respectively:

$$
\begin{aligned}
& \mathrm{pH}=-\log \left(\frac{\frac{\mathrm{m}_{0}}{120}}{\frac{\pi \mathrm{D}^{2} \mathrm{H} \theta}{4}}\right) \\
& \mathrm{C}_{\mathrm{SO}_{4}^{-2}}=\frac{\frac{2 \mathrm{~m}_{0}}{120}}{\frac{\pi \mathrm{D}^{2} \mathrm{H} \theta}{4}}
\end{aligned}
$$

\section{EXPERIMENTAL}

Guevara et al. (2008) evaluated the generation of drainage in columns using two coal mine wastes, named "São Roque" and "Volta Redonda". The mines are located in Santa Catarina state, Brazil. The chemical composition of the two wastes is shown in Table 1. The column used in the experiments was made of acrylic (50 cm height and $10 \mathrm{~cm}$ diameter). The air inlet was located in the bottom of the column.

Table 1: Chemical composition of coal wastes from the São Roque and Volta Redonda mines (Guevara et al., 2008).

\begin{tabular}{|c|c|c|}
\hline $\begin{array}{c}\text { Chemical species } \\
\text { (\%) }\end{array}$ & $\begin{array}{c}\text { São Roque's } \\
\text { waste }\end{array}$ & $\begin{array}{c}\text { Volta Redonda's } \\
\text { waste }\end{array}$ \\
\hline $\mathrm{Al}_{2} \mathrm{O}_{3}$ & 20.00 & 19.20 \\
$\mathrm{SiO}_{2}$ & 47.20 & 47.90 \\
$\mathrm{CaO}$ & 0.18 & 0.21 \\
$\mathrm{MgO}$ & 0.31 & 0.39 \\
$\mathrm{Fe}_{2} \mathrm{O}_{3}$ & 5.60 & 3.40 \\
$\mathrm{~S}_{\text {total }}$ & 4.10 & 1.70 \\
$\mathrm{~S}_{\text {sulphate }}$ & 0.70 & 0.65 \\
$\mathrm{~S}_{\text {pyritic }}$ & 3.32 & 1.05 \\
\hline
\end{tabular}

The columns were loaded with $3.4 \mathrm{~kg}$ of dried waste $(100 \%$ below a $25.4 \mathrm{~mm}$ screen). At the start of the run $(\mathrm{t}=0)$, both samples were moistened with distilled water three times using a peristaltic pump (the water inlet was located at the top of the column). 
Column operation comprised sequential dry and saturation cycles during 6 months. In the dry cycle, moist air was fed to the column during 6 days; then, on the seventh day, the column was saturated with distilled water for 24 hours (saturation cycle). After each saturation cycle, water was fully drained from the bottom of the column and a sample of aqueous solution was collected for chemical analysis by atomic absorption to determine the content of $\mathrm{Al}$, $\mathrm{Mn}, \mathrm{Pb}$ and $\mathrm{Zn}$. Other parameters such as $\mathrm{pH}$, Eh and conductivity were also measured.

\section{RESULTS AND DISCUSSION}

\section{Hydraulic Behaviour}

One important task to evaluate the humidity in mining wastes is to estimate the hydraulic properties related to the water retention curve in the mineral matrix. As an approach, sand is commonly used to describe the hydrodynamic processes related to AMD (Molson et al., 2008). Table 2 shows the hydraulic properties used in this study to simulate the water flow through the column.

Table 2: Hydraulic properties used in the simulations of the hydraulic description.

\begin{tabular}{|c|c|c|c|c|c|}
\hline $\begin{array}{c}\mathbf{K}_{\mathbf{0}} \\
\left(\mathbf{m ~ m i n}^{-\mathbf{1}}\right)\end{array}$ & $\begin{array}{c}\boldsymbol{\alpha} \\
\left(\mathbf{m}^{-\mathbf{1}}\right)\end{array}$ & $\begin{array}{c}\mathbf{n} \\
\mathbf{( - )}\end{array}$ & $\begin{array}{c}\mathbf{m} \\
\mathbf{( - )}\end{array}$ & $\begin{array}{c}\boldsymbol{\theta}_{\mathbf{0}} \\
\left(\mathbf{m}^{\mathbf{3}} \mathbf{m}^{-\mathbf{3}}\right)\end{array}$ & $\begin{array}{c}\boldsymbol{\theta r} \\
\left(\mathbf{m}^{\mathbf{3}} \mathbf{~ m}^{\mathbf{- 3}}\right)\end{array}$ \\
\hline $10^{-3}$ & 4 & 17 & 0.9 & 0.4 & 0.01 \\
\hline
\end{tabular}

Figures 1(a) and 1(b) exhibit the simulations for the velocity of water and humidity along the column length with time during water percolation, respectively. It can be seen that the velocity of water decreases to a minimum value near $0.002 \mathrm{~m} \mathrm{~min}^{-1}$ in the condition of saturation. This occurs due to the decrease in the hydraulic gradient during the percolation process. In addition, the humidity profile reveals that approximately $0.32 \mathrm{~m}$ of the column $(64 \%)$ is saturated after $50 \mathrm{~min}$ of infiltration, so the column is fully saturated after 100 min under the given conditions.

\section{Kinetic-Diffusive Behaviour}

Drainage quality for the coal mine wastes from the São Roque and Volta Redonda mines (Santa Catarina state, Brazil) were simulated in this study using column leaching tests. The main parameters adopted in the simulations are shown in Table 3 and theoretical results were confronted with experimental column data obtained by Guevara et al. (2008).

Table 3: Main properties used in the simulations of the chemical description.

\begin{tabular}{|l|r|}
\hline \multicolumn{1}{|c|}{ Parameter } & Value \\
\hline Porosity (-) & 0.4 \\
Particle diameter (mm) & 5.6 \\
Non reacted initial fraction (-) & 0.95 \\
Henry law constant (-) & 33.2 \\
Mineral density $\left(\mathrm{kg} \mathrm{m}^{-3}\right)$ & 1836 \\
Initial oxygen concentration $\left(\mathrm{g} \mathrm{m}^{-3}\right)$ & 0.3 \\
Waste rock oxygen diffusive coefficient $\left(\mathrm{m}^{2} \mathrm{yr}^{-1}\right)$ & 75 \\
Mineral grain oxygen diffusive coefficient $\left(\mathrm{m}^{2} \mathrm{yr}^{-1}\right)$ & $10^{-6}$ \\
Pyritic sulphur (\%) & 3.3 \\
Water oxygen diffusion coefficient $\left(\mathrm{m}^{2} \mathrm{yr}^{-1}\right)$ & 0.07 \\
\hline
\end{tabular}

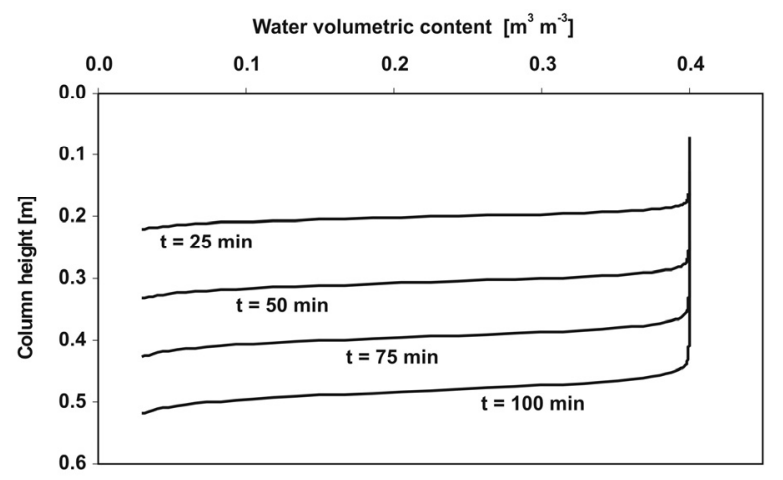

(a)

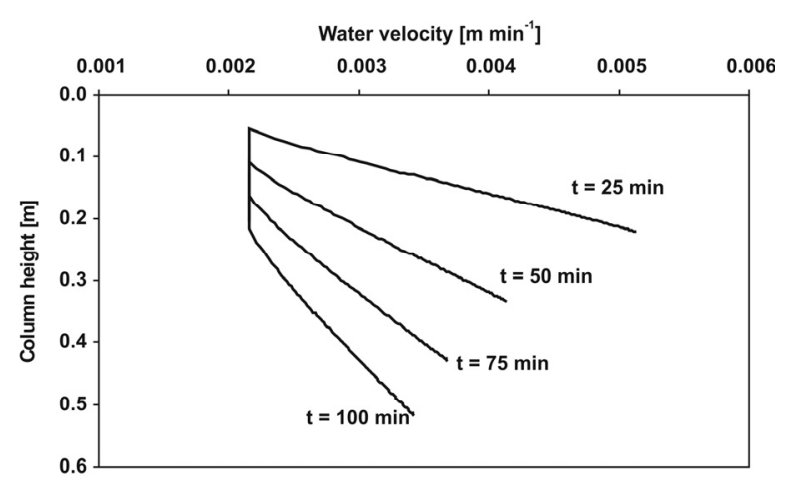

(b)

Figure 1: Hydraulic simulation: (a) humidity curves profile, (b) water velocity infiltration through the column. 
Firstly, the model was calibrated using the parameter $\mathrm{f}_{\mathrm{m}}$ by fitting the experimental $\mathrm{pH}$ at the exit of the column. Figure 2(a) exhibits the simulation results for the $\mathrm{pH}$ at the exit of the column for changing values of $f_{m}$ for the waste of the São Roque coal mine. According to the model, an increase in the microbiological factor $\mathrm{f}_{\mathrm{m}}$ resulted in lower $\mathrm{pH}$ values, thus indicating that microorganisms significantly affect the increase in AMD generation. As shown in Figure 2(a) for the waste of São Roque, $\mathrm{f}_{\mathrm{m}} \approx 3 \times 10^{7}$ (the relative deviation error between experimental and simulated $\mathrm{pH}$ values was around $5 \%$ ). The high value of $\mathrm{f}_{\mathrm{m}}$ corroborates previous studies which verified that the presence of microorganisms might increase the reaction rate by many orders of magnitude $\left(10^{5}\right.$ up to $10^{8}$ times) compared to purely chemical oxidation rates (Baker and Wilshire, 1970; McBride, 1994).

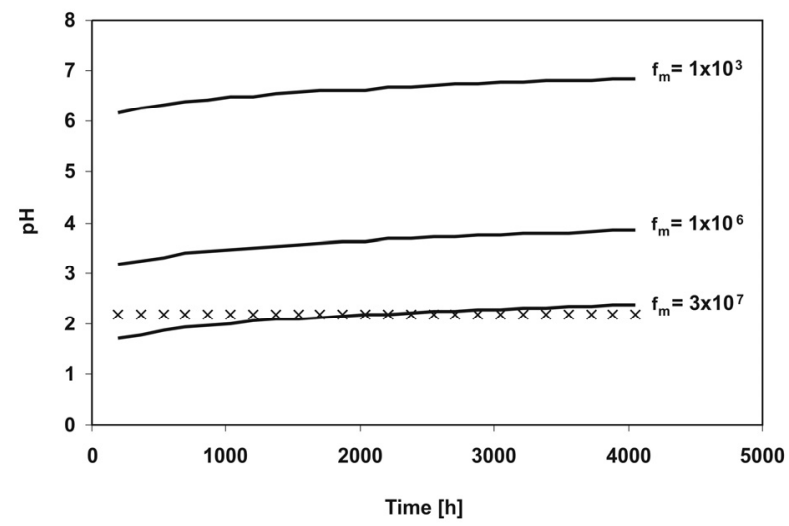

(a)
Consequently, an increase in $\mathrm{f}_{\mathrm{m}}$ will be reflected in a higher concentration of sulphate in the aqueous drainage as verified in Figure 2(b) for the waste of São Roque (despite of fluctuation in the experimental values, the simulated curve indicates that sulphate concentrations range from 0.5 to nearby $3.0 \mathrm{~g} / \mathrm{L}$ ). The decrease in the concentration of sulphate with time shown in Figure 2(b) and the consequent small increase in $\mathrm{pH}$ shown in Figure 2(a) are due to the consumption of pyrite in the column, which decreased from 0.4 to $0.1 \mathrm{~g}$ day $^{-1}$ while the calculated oxidation rate decreased from 180 to $40 \mathrm{~g} \mathrm{~m}^{-3}$ day $^{-1}$ of oxygen during six months (see Figure 3(a), total oxidation of pyrite $\approx 13 \%$ ). The same trends were obtained by fitting data for the coal waste of the Volta Redonda mine $\left(\mathrm{f}_{\mathrm{m}} \approx 2.5 \times 10^{7}\right.$ with an average relative deviation in $\mathrm{pH}$ of 5\%) as can be seen in Figure 3(b) for the total oxidation of pyrite with time.

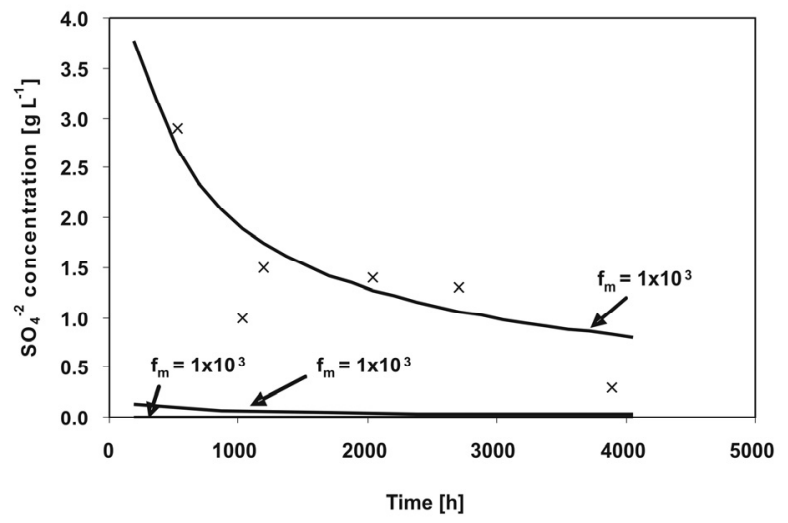

(b)

Figure 2: Calibration of the kinetic-diffusive description for changing microbiological factors $f_{m}$ (coal mine waste of São Roque): (a) transient $\mathrm{pH}$ in the acid solution, (b) transient sulphate concentration in the acid solution.

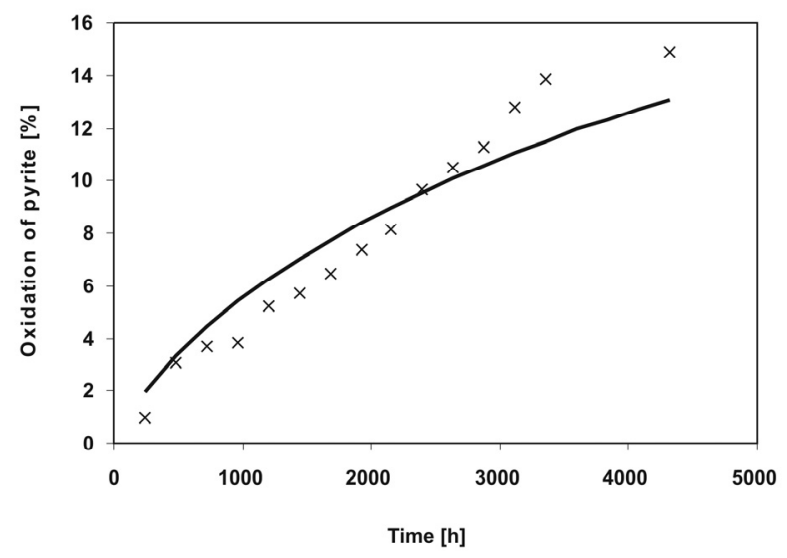

(a)

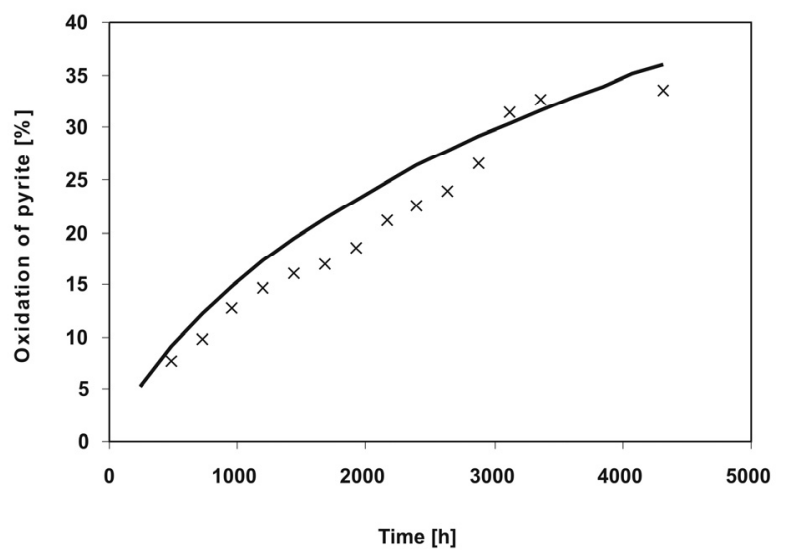

(b)

Figure 3: Comparison between experimental and simulated oxidation of pyrite with time: (a) waste of São Roque, (b) waste of Volta Redonda. 
Because the model reproduced the experimental behaviour satisfactorily for the column operation, it was then used to analyse the influence of parameters such as oxygen diffusion coefficient $\left(D_{e}\right)$, pyrite content $\left(f_{s}\right)$ and average particle radius $(\mathrm{R})$ on the AMD generation, on the intrinsic oxidation rate (IOR) and on the $\mathrm{pH}$ of the aqueous solution with time. Theoretical trends are shown respectively in Figures 4, 5 and 6. As verified in

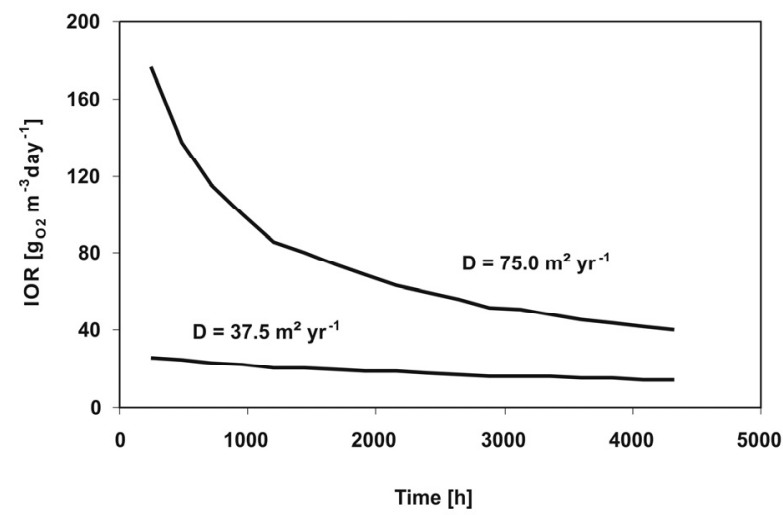

(a)
Figure 4, the oxygen diffusive coefficient affects negatively the oxidation rate of pyrite; consequently, higher $\mathrm{pH}$ values are obtained. As expected, the opposite behaviour is verified if the content of pyrite is doubled (see Figure 5). Finally, as shown in Figure 6, the lower the granulometry of the waste, the higher is the generation of AMD, so a higher negative impact is expected because a more acidic effluent is obtained.

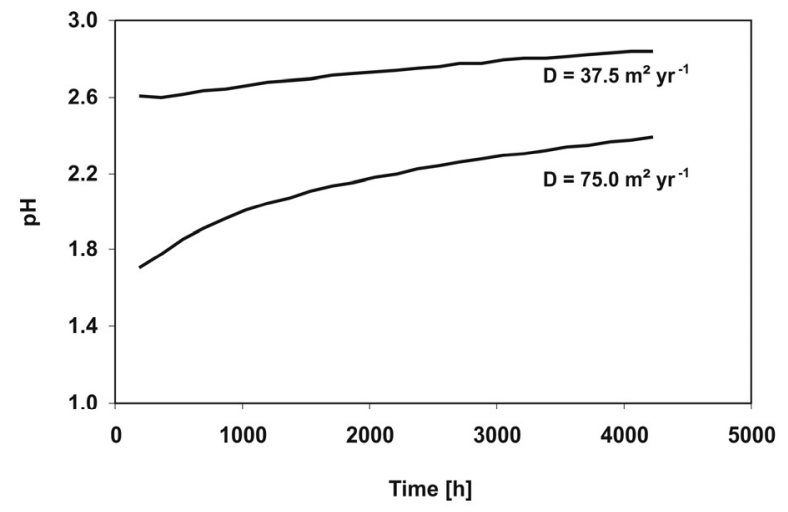

(b)

Figure 4: Effect of the effective oxygen diffusion coefficient: (a) intrinsic oxidation rate (IOR) and (b) $\mathrm{pH}$ of the aqueous solution.

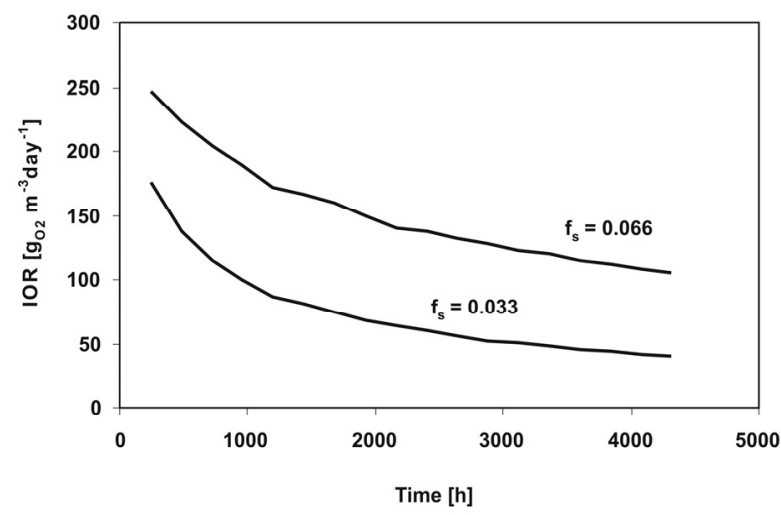

(a)

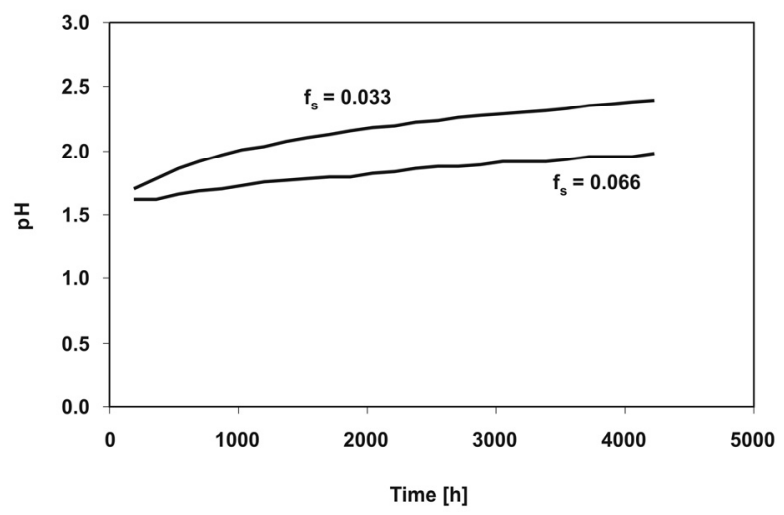

(b)

Figure 5: Effect of the initial content of pyrite: (a) intrinsic oxidation rate (IOR) and (b) $\mathrm{pH}$ of the aqueous solution.

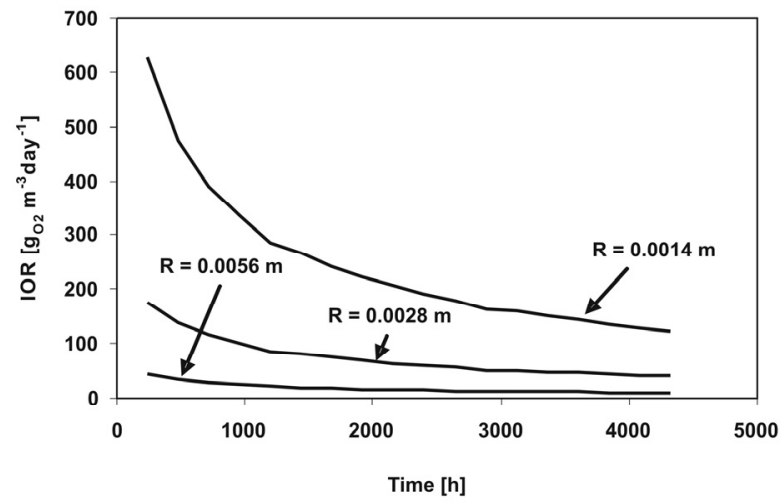

(a)

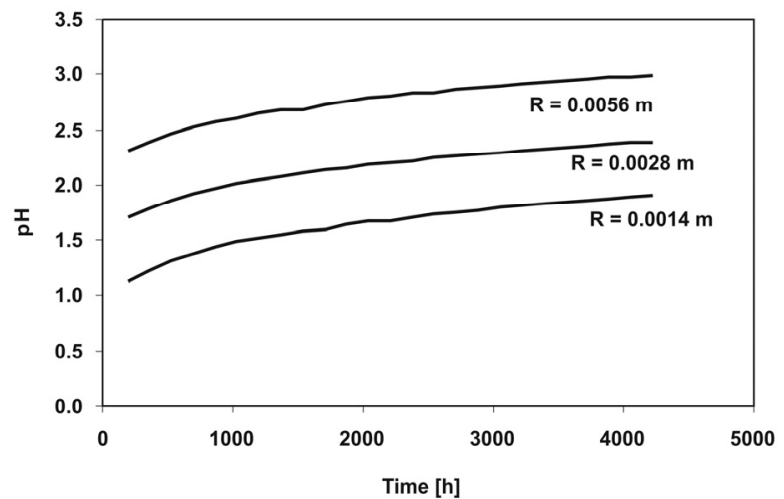

(b)

Figure 6: Effect of the particle size: (a) intrinsic oxidation rate (IOR) and (b) $\mathrm{pH}$ of the aqueous solution. 


\section{CONCLUSIONS}

The model proposed in this paper was found to reproduce the experimental behaviour from leaching column tests using two different wastes from coal mines located in Santa Catarina state, in Brazil. Based on the simulations confronted with experimental data, the following main conclusions can be drawn for the conditions investigated:

- The column reaches saturation within 100 minutes and the velocity of water infiltration ranges from 0.002 to $0.005 \mathrm{~m} \mathrm{~min}^{-1}$;

- The model satisfactorily predicted the $\mathrm{pH}$ of the aqueous phase within 5\% deviation;

- The quality of the prediction depends strongly on the microbiological factor $\left(f_{m}\right)$, so reaction rate equations to describe the pyrite oxidation incorporating microorganism effects are urged to be developed in order to improve AMD prediction.

\section{ACKNOWLEDGMENTS}

Authors are grateful to Prof. Vicente Paulo Souza (CETEM-Rio de Janeiro, Brazil) and Prof. Celso Luiz Prevedello (UFPR-Paraná, Brazil), as well as to the National Institute of Science and Technology (INCT, Brazil): Mineral Resources, Water and Biodiversity(MCT/CNPq/FNDCT/CAPES/FAPEMIG/ FAPERJ/FAPESP) for the financial support.

\section{NOMENCLATURE}

\begin{tabular}{|c|c|c|}
\hline $\mathrm{C}_{\mathrm{o} 2}$ & Oxygen concentration & $\mathrm{g} \mathrm{m}^{-3}$ \\
\hline $\mathrm{D}_{\mathrm{e}}$ & Oxygen diffusion coefficient & $\mathrm{m}^{2} \mathrm{yr}^{-1}$ \\
\hline $\mathrm{D}_{2}$ & $\begin{array}{l}\text { Oxygen diffusion coefficient } \\
\text { within mineral grain }\end{array}$ & $\mathrm{m}^{2} \mathrm{yr}^{-1}$ \\
\hline $\mathrm{D}_{\mathrm{w}}$ & $\begin{array}{l}\text { Water oxygen diffusion } \\
\text { coefficient }\end{array}$ & $\mathrm{m}^{2} \mathrm{yr}^{-1}$ \\
\hline $\mathrm{D}$ & Column diameter & 11 \\
\hline $\mathrm{f}_{\mathrm{m}}$ & Microbiological factor & $(-)$ \\
\hline $\mathrm{H}$ & Henry law constant & $(-)$ \\
\hline h & Matric potential & $\mathrm{m}$ \\
\hline $\mathrm{K}_{\mathrm{i}}$ & $\begin{array}{l}\text { Initial hydraulic } \\
\text { conductivity }\end{array}$ & $\mathrm{m} \min ^{-1}$ \\
\hline $\mathrm{K}_{0}$ & $\begin{array}{l}\text { Hydraulic conductivity at } \\
\text { saturation }\end{array}$ & $\mathrm{m} \min ^{-1}$ \\
\hline $\mathrm{m}_{0}$ & $\begin{array}{l}\text { Pyrite mass oxidized at } \\
\text { column }\end{array}$ & $\mathrm{g}$ \\
\hline Ps & Pyrite/Sulfur mass ratio & $(-)$ \\
\hline $\mathrm{R}$ & Particle radius & $\mathrm{nm}$ \\
\hline$r_{c}$ & Non-reacted particle radius & $\mathrm{mm}$ \\
\hline $\mathrm{S}_{0}$ & Intrinsic oxidation rate & $m^{-3}$ day $^{-1}$ \\
\hline
\end{tabular}

$\mathrm{t} \quad$ time

z Column position

$\min$

$\mathrm{m}$

\section{Greek Letters}

$\theta \quad$ Water volumetric content

$\mathrm{m}^{3} \mathrm{~m}^{-3}$

$\theta_{\text {eq }} \quad$ Equivalent air volumetric

$\mathrm{m}^{3} \mathrm{~m}^{-3}$

$\theta_{\mathrm{r}}$ content

$\theta_{\mathrm{r}} \quad$ Residual water content $\mathrm{m}^{3} \mathrm{~m}^{-3}$

\section{REFERENCES}

Bain, J., Blowes, D. W., Robertson, W. D. and Frind, E. O., Modelling of sulfide oxidation with reactive transport at a mine drainage site. J. Contam. Hydrol., 41, 23-47 (2000).

Baker, R. A. and Wilshire, A. G., Microbiological factor in acid mine drainage formation: a pilot plant study. Environ. Sci. Technol., 4, 401-407 (1970).

Barry, D. A., Parlange, J. -Y., Prevedello, C. L., Loyola, J. M. T., Reichardt, K. and Nielsen, D. R., Extension of a recent method for obtaining exact solutions of the Bruce and Klute equation. Vadose Zone J., 6, 496-498 (2010).

Edwards, K. J., Bond. P. L., Druschel, G. K., McGuire, M. H., Harmes, R. J. and Banfield, J. F., Geochemical and biological aspects of sulfide mineral dissolution: lessons from iron mountain. California, Chem. Geology, 169, 383-397 (2000).

Elberling, B., Nicholson, R. V. and Scharer, J. M., A combined kinetic and diffusive model for pyrite oxidation in tailings: a change in controls with time. J. Hydrology, 157, 47-60 (1994).

Eriksson, N. and Destouni, G., Combined effects of dissolution kinetics, secondary mineral precipitation and preferential flow on copper leaching from mining waste rock. Water Resources Res., 33, 471-483 (1997).

Guevara, L. R. Z., Souza, V. P., Moura, F. J. and Bertolino, L. C., Potential prediction of acid mine drainage from coal mine wastes employing leaching column kinetic method, In: Proc. of the 8th Int. Conf. Clean Technologies for the World Mining Industry. Advances in Cleaner Technologies for the Mining and Metallurgical Industry, Santiago, Chile (2008).

Levenspiel, O., Chemical Reaction Engineering, 2nd Ed., J. Wiley and Sons, New York (1972).

Mayer, K. U., Frind, E. O. and Blowes, D. W., Multicomponent reactive transport modeling in variably saturated porous media using a generalized formulation for kinetically controlled 
reactions. Water Resour. Res., 38, 1174-1195 (2002).

Martin, J., Wiatzka, G., Scharer, J. and Halbert, B., Case studies that illustrate the benefits, limitations and information requirements of geochemical modeling. In: Proc. of the $12^{\text {th }}$ Annual British Columbia - MEND Metal Leaching/ Acid Rock Drainage Workshop, Vancouver, Canada (2005).

McBride, M. B., Environmental chemistry of soils. New York, Oxford University Press (1994).

Mend Report, Prediction manual for drainage chemistry from sulphidic geologic materials, 1.20.1. Canada (2009).

Molson, J. W., Fala O., Aubertin, M., Bussiere, B. and Benzazoua, M., Geochemical transport modelling of drainage from experimental mine tailings cells covered by capillary barriers. Applied Geochem., 23, 1-24 (2008).
Nicholson, R. V., Rinker, M. J., Acott, G. and Venhuis, M. A., Integration of field data and a geochemical transport model to assess mitigation strategies for an acid-generating mine rock pile at a uranium mine. In: Proc. of the Sudbury 2003: Mining and the Environment, Canada (2003).

Prevedello, C. L., Loyola, J. M. T., Reichardt, K. and Nielsen, R., New analytic solution related to the Richards, Philip and Green-Ampt equations for infiltration. Vadose Zone J., 8, 127-135 (2009).

Schneider, P., Osenbrueck, K., Neitzel, P. L. and Nindel, K., In-situ mitigation of effluents from acid waste rock dumps using reactive surface barriers - a feasibility study. Mine Water Environ., 21, 36-44 (2002).

van Genuchten, M. T., A closed-form equation for predicting the hydraulic conductivity of unsaturated soils. Soil Sci. Soc. Am. J., 44, 892898 (1980). 